\title{
ECOTOXICOLOGICAL BEHAVIOUR OF POORLY WATER SOLUBLE FATTY ALCOHOL ETHOXYLATES IN FRESHWATER ENVIRONMENT
}

\section{SITI AFIDA ISHAK*; NOORAZAH ZOLKARNAIN* and RAZMAH GHAZALI*}

\begin{abstract}
Fatty alcohol ethoxylates (FAEO) are widely used for a wide range of applications. Due to their excessive and widespread use, the ecotoxicological behaviour of FAEO in aquatic environment is crucial in managing the environmental sustainability. The objective of this study is to determine the ecotoxicology behaviour, i.e. biodegradation and ecotoxicity, of poorly water soluble lauryl alcohol ethoxylates $\left(C_{12}\right)$ with different ethoxylate numbers, i.e. EO3, EO5, EO6, EO7 and EO10. For ecotoxicity test, OECD 209, activated sludge, respiration inhibition test method was used. This method was selected as a rapid screening test to identify substances that have unfavourable influence on microorganisms in sewage treatment plant and also to identify non-inhibitory concentration of test substances applicable for biodegradation test. Meanwhile, the biodegradation test was performed using OECD 301C, MITI (I) (Ministry of International Trade and Industry, Japan) test method. The biodegradability of this surfactant was monitored for 28 days. The results of OECD 209 showed only FAEO (EO3) with a maximum concentration of $1000 \mathrm{mg}^{\text {litre }} \mathrm{e}^{-1}$ inhibited more than $50 \%$ respiration of activated sludge, while other FAEO samples inhibited less than $50 \%$ after $3 \mathrm{hr}$ of exposure. The $3 \mathrm{hr}$ of half maximal effective concentration $\left(E C_{50}\right.$ ) for FAEO (EO3) for activated sludge was $423 \mathrm{mg} \mathrm{litre}^{-1}$ while, for other FAEO samples was $>1000 \mathrm{mg} \mathrm{litre}^{-1}$. The toxicity effect decreased with increasing $E O$ number. For biodegradation test, the results indicated that $F A E O$ were readily biodegraded in OECD 301C where their biodegradability surpassed the $60 \%$ pass level as stated in the standard method and can be considered as readily biodegradable in the environment. As the EO chain length increased, the hydrophilic-lipophilic balance (HLB) of FAEO tended to increase while the hydrophobicity tended to decrease. The reduction in hydrophobicity level increases its solubility in water, thus promotes rapid biodegradation in aquatic environment.
\end{abstract}

\section{Keywords: nonionic surfactant, ecotoxicity, activated sludge, biodegradation.}

Received: 17 October 2019; Accepted: 13 February 2020; Published online: 28 August 2020.

\section{INTRODUCTION}

Surfactants are surface-active agent that are widely used inhousehold and ind ustrial cleaning detergents, personal care products and pharmaceuticals. The

\footnotetext{
Malaysian Palm Oil Board,

6 Persiaran Institusi, Bandar Baru Bangi,

43000 Kajang, Selangor, Malaysia.

E-mail: siti.afida@mpob.gov.my
}

global surfactants market was valued at RM 43655 million in 2017, and is projected to reach RM 64408 million by 2025 (Allied Market Research, 2018). Due to their extensive use, surfactants can be a possible toxicant when large quantity enter the environment via wastewaters (Jasna and Tomislav, 2007). Therefore, it is important for all new surfactants to have product safety datasheet, which includes the environmental protection parameters, i.e. biodegradation and ecotoxicity (Linda, 2012). 
Some surfactants are poorly soluble in water and they are also discharged with sewage just like the soluble surfactants. This means the biodegradability of poorly water-soluble substances should be assessed and treated the same as soluble surfactants. However, the methodology for measurement of biodegradability of poorly water soluble substances is less developed compared to soluble substances. According to European Centre for Ecotoxicology and Toxicology of Chemicals (ECETOC, 1986), a few standard methods such as closed bottle test, modified Organisation for Economic Co-operation and Development (OECD) screening test, modified Association Française de Normalisation (AFNOR) test, modified sturm test and modified Ministry of International Trade and Industry, Japan (MITI) tests are considered suitable for testing poorly water soluble substances.

Fatty alcohol ethoxylates (FAEO) a nonionic surfactant is widely used in household laundry detergents, industrial cleaners, cosmetics and agriculture (Baumann and Biermann, 1994). FAEO are synthesised via ethoxylation of fatty alcohol (FA) with ethylene oxide (EO). The sources of FA could be either palm kernel oil (PKO), coconut oil or petrochemicals. In 2018 alone, in order to serve high demand from domestic oleochemicals plant, Malaysia increased imports of PKO by $32.4 \%$ compared to 2017 (182 106 t) (Kushairi et al., 2019). The solubility of FAEO in water depends on its chain length and the degree of ethoxylation.

The occurrence of FAEO in aquatic environment and sewage treatment plant has been monitored by many countries. In the Netherlands, the concentrations of FAEO in effluent vary between 0.0022 and $0.013 \mathrm{mg} \mathrm{litre}^{-1}$ with an average value of $0.0062 \mathrm{mg} \mathrm{litre}^{-1}$ (Matthijs et al., 1999). The presence of FAEO in the aquatic environment has also been reported in Japanese rivers, where the concentration of FAEO was below the detection limit of $0.005 \mathrm{mg}$ litre $^{-1}$, whereas the concentration in the sediment ranged from 0 to $1.0 \mathrm{mg} \mathrm{kg}^{-1}$. In Ohio River, USA, the concentration of FAEO $\mathrm{C}_{14-15}$ was $0.004 \mathrm{mg}$ litre $^{-1}$. Meanwhile, total concentrations of FAEO in wastewater treatment plant (WWTP) effluents in Europe, Canada and the United States were between 1 to $23 \mu$ litre $^{-1}$ (Matthijs et al., 1999; Eadsforth et al., 2006; Morrall et al., 2006). Environmental risk assessments of FAEO have been reported in many studies such as by Goyer et al. (1981), Talmage (1994) and Van De Plassche et al. (1999). These assessments are becoming increasingly sophisticated due to advances in understanding analytical methods, exposure, fate and effects of FAEO in the environment.

Ecotoxicity behaviour of linear FAEO has been observed by Talmage (1994) and HERA (2009) using a few test species such as fish, daphnia and freshwater algae. It was found that the ecotoxicity or half maximal effective concentration $\left(\mathrm{EC}_{50}\right)$ of FAEO towards algae, daphnia and fish were in the range of 0.1 to $100 \mathrm{mg}$ litre $^{-1}$. For branched FAEO, toxicity value ranged from $0.5 \mathrm{mg}$ litre $^{-1}$ to $50 \mathrm{mg}$ litre $^{-1}$. The $\mathrm{EC}_{50}$ values for linear and branched FAEO towards algae were $0.05 \mathrm{mg}$ litre $^{-1}$ to $50 \mathrm{mg}$ litre $^{-1}$. The half maximal lethal concentration $\left(\mathrm{LC}_{50}\right)$ value of linear FAEO towards fish was between $0.4 \mathrm{mg}$ litre $^{-1}$ and $100 \mathrm{mg} \mathrm{litre}^{-1}$, while for branched FAEO, $\mathrm{LC}_{50}$ range was from $0.25 \mathrm{mg} \mathrm{litre}^{-1}$ to $40 \mathrm{mg} \mathrm{litre}^{-1}$. Swisher (1987) suggested the toxicity increases with an increase in the alkyl chain length and decreases with an increase in the ethoxylate chain length.

Relationships between surfactant structure (particularly EO groups) and toxicity towards aquatic organisms have been observed previously. Diana et al. (1997) showed the toxicity of FAEO towards fathead minnow and D. magna tended to increase as the surfactant structure becomes more hydrophobic (high alkyl or low EO chain length). The same observation was made by Maki and Bishop (1979) using D. magna as a test species. According to Hall et al. (1989), ethoxylated alkylphenols $(\mathrm{EO}>30)$ showed low toxicity towards Mysidopsis bahia. The ecotoxicity study by Guhl and Gode (1989) found that the toxicity of three FAEO surfactants $\left(\mathrm{C}_{12-18} \mathrm{EO}_{10}, \mathrm{C}_{16-18} \mathrm{EO}_{14}\right.$ and $\left.\mathrm{C}_{12-14} \mathrm{EO}_{30}\right)$ towards fish and Daphnia sp. decreased with increasing $\mathrm{EO}$ numbers. Wildish (1976) studied the toxicity effect of surfactants liposolubility towards fish and found that toxicity of polyoxyethylene esters, ethers, and amines in oil dispersants decreased with increasing EO numbers.

The biodegradation of FAEO has been widely studied in many laboratories and field conditions. Most of these biodegradation tests with FAEO were performed under aerobic conditions, and only a few under anaerobic conditions (Markus, 2000). Majority of FAEO biodegradation process occurs in the sewage system or WWTP. Linear alcohol ethoxylate was found to be readily biodegradable and released degradation products such as free fatty alcohol (FFA) and poly(ethylene glycols) (PEG) (Environment Canada, 2003). Kravetz et al. (1984) observed that linear and branched FAEO were biodegraded more than $80 \%$ and $40 \%$, respectively, in 28 days.

Although many ecotoxicology studies have been conducted on water-soluble FAEO, limited studies are available for poorly water-soluble FAEO (with EO less than 10). The aim of this work was to study the ecotoxicological behaviour of poorly water-soluble FAEO in order to establish their impact on the environment. 


\section{MATERIALS AND METHODS}

\section{Materials}

The studied test substances were commercial lauryl $\left(\mathrm{C}_{12}\right)$ alcohol ethoxylates (FAEO) with different ethoxylate numbers, i.e. EO3, EO5, EO6, EO7 and EO10. Table 1 shows the hydrophiliclipophilic balance (HLB) value and molecular weight of the test substances. Reference substances used for biodegradation test was aniline (99\%) from AnalaR-BDH, Germany and 3,5-dichlorophenol (99\%) from Sigma Aldrich, USA for ecotoxicity test.

\begin{tabular}{lccccc} 
TABLE 1. HYDROPHILIC-LIPOPHILIC BALANCE (HLB) \\
VALUE AND MOLECULAR WEIGHT OF \\
COMMERCIAL C $_{12}$ FAEO \\
\hline $\begin{array}{r}\text { FAEO } \\
\text { (EO3) }\end{array}$ & $\begin{array}{c}\text { FAEO } \\
\text { (EO5) }\end{array}$ & $\begin{array}{c}\text { FAEO } \\
\text { (EO6) }\end{array}$ & $\begin{array}{c}\text { FAEO } \\
\text { (EO7) }\end{array}$ & $\begin{array}{c}\text { FAEO } \\
\text { (EO10) }\end{array}$ \\
\hline HLB & 9 & 10.5 & 11 & 12 & 13 \\
$\begin{array}{l}\text { Molecular } \\
\text { weight }\end{array}$ & 340 & 430 & 470 & 500 & 630 \\
& & & & & \\
\hline
\end{tabular}

\section{Measurement of Ecotoxicity of FAEO}

Sludge inoculum. Activated sludge collected from a sewage treatment plant in Indah Water Konsortium (IWK), Putrajaya, Malaysia, was washed with water. After centrifuging the sludge at $6000 \mathrm{rpm}$ for $10 \mathrm{~min}$, the supernatant was decanted. About $3 \mathrm{~g}$ of the washed sludge was dissolved in 1 litre distilled water. The sludge inoculum was aerated for $20 \mathrm{hr}$ before used.

Reference substance. Reference substance 3,5-dichlorophenol was tested at different concentrations, i.e. $1 \mathrm{mg}$ litre $^{-1}, 6 \mathrm{mg}$ litre $^{-1}$ and 12 $\mathrm{mg}$ litre $^{-1}$, under the same test conditions as the test substance in order to check the sensitivity of sludge inoculum.

\section{Preparation of Test Solution}

Synthetic sewage feed. The synthetic sewage feed was prepared using analytical grade reagents as given in Table 2. The final volume was 1 litre. The $\mathrm{pH}$ of the synthetic feeding solution was set at $7.5 \pm$ 0.5 and stored at $4^{\circ} \mathrm{C}$ until used.

Six 1 litre schott bottles were prepared for determination of blank, reference substance (3,5-dichlorophenol) and test substance oxygen respiration rate $(\mathrm{R})$ in simultaneous experimental series. Each series was prepared in triplicate. Reference substance was tested at three concentrations, i.e. 1, 6 and $12 \mathrm{mg}$ litre $^{-1}$, while test substance was tested at 10, 100 and $1000 \mathrm{mg} \mathrm{litre}^{-1}$. In each of test bottle, $16 \mathrm{ml}$ of synthetic sewage feed and $250 \mathrm{ml}$ of sludge inoculum were added. Then, the test bottle was filled with water up to $500 \mathrm{ml}$.

All bottles were closed with a stopper and aerated with air bubbles for $3 \mathrm{hr}$, then stirred and incubated at $22 \pm 2^{\circ} \mathrm{C}$ in the dark. After $3 \mathrm{hr}$ of incubation, the $\mathrm{R}$ value was determined by measuring the decrease of oxygen content for $10 \mathrm{~min}$ using dissolved oxygen meter (Multi 3410 WTW, Germany). During the measurement, the stirring was continued but the aeration was stopped.

The percentage of respiration inhibition $\left(\mathrm{I}_{\mathrm{TI}} \%\right)$ was calculated as bellows:

$$
\mathrm{I}_{\mathrm{TI}}=100-\left[\left(\mathrm{R}_{\mathrm{TI}}{ }^{*} 100\right) / \mathrm{R}_{\mathrm{c}}\right]
$$

where,

$\mathrm{R}_{\mathrm{TI}}=\mathrm{O}_{2}$ respiration rate of test item solutions [mg $\mathrm{O}_{2}$ litre $^{-1} \mathrm{hr}^{-1}$ ]

$\mathrm{R}_{\mathrm{c}}=\mathrm{O}_{2}$ respiration rate of control (mean) $\left[\mathrm{mg} \mathrm{O}_{2}\right.$ litre $^{-1} \mathrm{hr}^{-1}$ ]

TABLE 2. PREPARATION OF 1 litre OF SYNTHETIC SEWAGE FEED

\begin{tabular}{|c|c|}
\hline Chemical & $\begin{array}{l}\text { Amount } \\
(\mathrm{g})\end{array}$ \\
\hline Peptone & 16.0 \\
\hline Meat extract & 11.0 \\
\hline Urea & 3.0 \\
\hline Sodium chloride $(\mathrm{NaCl})$ & 0.7 \\
\hline $\begin{array}{l}\text { Calcium chloride dehydrate } \\
\left(\mathrm{CaCl}_{2} \cdot 2 \mathrm{H}_{2} \mathrm{O}\right)\end{array}$ & 0.4 \\
\hline $\begin{array}{l}\text { Magnesium sulphate heptahydrate } \\
\left(\mathrm{MgSO}_{4} \cdot 7 \mathrm{H}_{2} \mathrm{O}\right)\end{array}$ & 0.2 \\
\hline $\begin{array}{l}\text { Dipotassim hydrogen phosphate } \\
\left(\mathrm{K}_{2} \mathrm{HPO}_{4}\right)\end{array}$ & 2.8 \\
\hline
\end{tabular}

\section{Measurement of Biodegradation of FAEO}

Inoculum. The standard activated sludge (1 litre) was collected at 10 different sampling sites such as sewage treatment plant, industrial waste-water treatment plant, rivers, lakes and seas in the Klang Valley, Malaysia. All the sludge samples from 10 different sampling sites were then mixed together and maintained at $25^{\circ} \mathrm{C}$ for three months by aerating it in mineral solution ( $\mathrm{pH} 7$ ) containing $0.1 \%$ each of glucose, peptone and potassium orthophosphate.

Mineral medium. The mineral medium solutions used in the biodegradation test OECD 301C are described in Table 3. 
TABLE 3. PREPARATION OF MINERAL STOCK SOLUTIONS

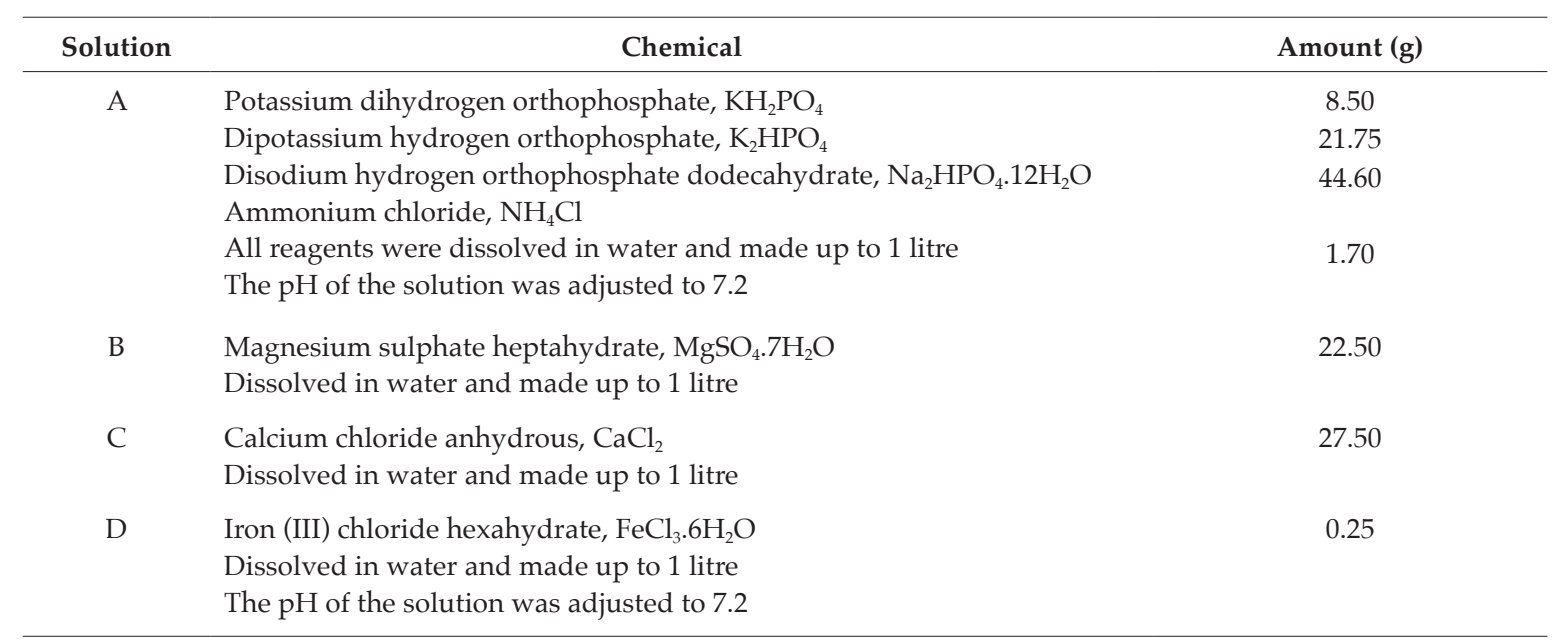

Source: OECD (1992).

The concentration of the test substance was $100 \mathrm{mg}$ litre $^{-1}$ and the inoculum concentration was $30 \mathrm{mg}$ litre ${ }^{-1}$ dry matter. Other important test parameters for this biodegradation tests are as outlined in the OECD 301C guidelines. The mineral medium solution and test and reference substance stock solutions were prepared using ultra-pure water (Arioso, Human Corporation, Korea).

\section{OECD 301C, MITI Method}

The biodegradation test was conducted according to OECD 301C MITI test, i.e. coulometer method. In a BOD test bottle, $100 \mathrm{mg}$ of FAEO sample and $30 \mathrm{mg}$ of inoculum were added to $300 \mathrm{ml}$ of mineral medium. The bottles were then stirred for 28 days and the biochemical oxygen demand (BOD) (ppm) was measured continuously with a BOD meter (Coulometer, Ohkura Electric Co. Ltd, Japan). The test substance was prepared in triplicate while reference substance was prepared in duplicate.

\section{Calculation of Biodegradability}

The biodegradability of FAEO was automatically calculated by the coulometer's software using the following formula.

$$
\begin{aligned}
\mathrm{BOD} & =\frac{\begin{array}{c}
\mathrm{mg} \mathrm{O}_{2} \text { uptake by test substance }- \\
\mathrm{mg} \mathrm{O}_{2} \text { uptake by blank }
\end{array}}{\mathrm{mg} \text { test substance in vessel }} \\
& =\mathrm{mg} \mathrm{O}_{2} \text { per } \mathrm{mg} \text { test substance }
\end{aligned}
$$

The percentage of biodegradation was then calculated by dividing the specific BOD with the specific theoretical oxygen demand (ThOD) or chemical oxygen demand (COD).

$$
\begin{aligned}
& \% \text { biodegradation }=\frac{\left(\mathrm{mg} \mathrm{O}_{2} \text { per } \mathrm{mg} \text { test substance }\right)}{\text { ThOD or COD }} \times 100 \\
& \text { (mg } \mathrm{O}_{2} \text { per } \mathrm{mg} \text { test substance) }
\end{aligned}
$$

ThOD was calculated based on the molecular weight (MW) and chemical formula $\left(\mathrm{C}_{\mathrm{c}} \mathrm{H}_{\mathrm{h}} \mathrm{Cl}_{\mathrm{cl}} \mathrm{N}_{\mathrm{n}} \mathrm{Na}_{\mathrm{na}} \mathrm{O}_{\mathrm{o}} \mathrm{P}_{\mathrm{p}} \mathrm{S}_{\mathrm{s}}\right)$.

$$
\operatorname{ThOD}\left(\mathrm{mg} \mathrm{mg}^{-1}\right)=\frac{\begin{array}{c}
16[2 \mathrm{c}+1 / 2(\mathrm{~h}-\mathrm{cl}-3 \mathrm{n})+3 \mathrm{~s} \\
+5 / 2 \mathrm{p}+1 / 2 \mathrm{na}-\mathrm{o}]
\end{array}}{\mathrm{MW}}
$$

Meanwhile, chemical oxygen demand (COD) was used to calculate the percentage of biodegradation when information on the molecular structure of the test substance is not available.

\section{RESULTS AND DISCUSSION}

\section{Ecotoxicity of FAEO Based on OECD 209, Activated Sludge Respiration Inhibition Test Method}

Ecotoxicity of reference substance. The $\mathrm{EC}_{50}$ value of reference sample, 3,5-dichlorophenol was $4.94 \mathrm{mg}$ litre $^{-1}$ (Figure 1). This value was within the accepted $\mathrm{EC}_{50}$ value for reference substance $\left(2 \mathrm{mg}\right.$ litre $^{-1}$ to $25 \mathrm{mg}$ litre $^{-1}$ ) as stipulated in OECD 209, activated sludge respiration inhibition test method. Thus, the activated sludge was sensitive and suitable to be used as inoculum in this study.

Ecotoxicity of FAEO. The ecotoxicity of commercial FAEO with different EO numbers (EO3, EO5, EO6, EO7 and EO10) were determined using OECD 209 (2010). The highest concentration used in this study was $1000 \mathrm{mg} \mathrm{litre}^{-1}$. The oxygen respiration rate for all FAEO samples at $1000 \mathrm{mg}$ litre $^{-1}$ was approximately between 6.42 to $15.18 \mathrm{mg}$ litre $\mathrm{hr}^{-1}$ oxygen (Table 4). 


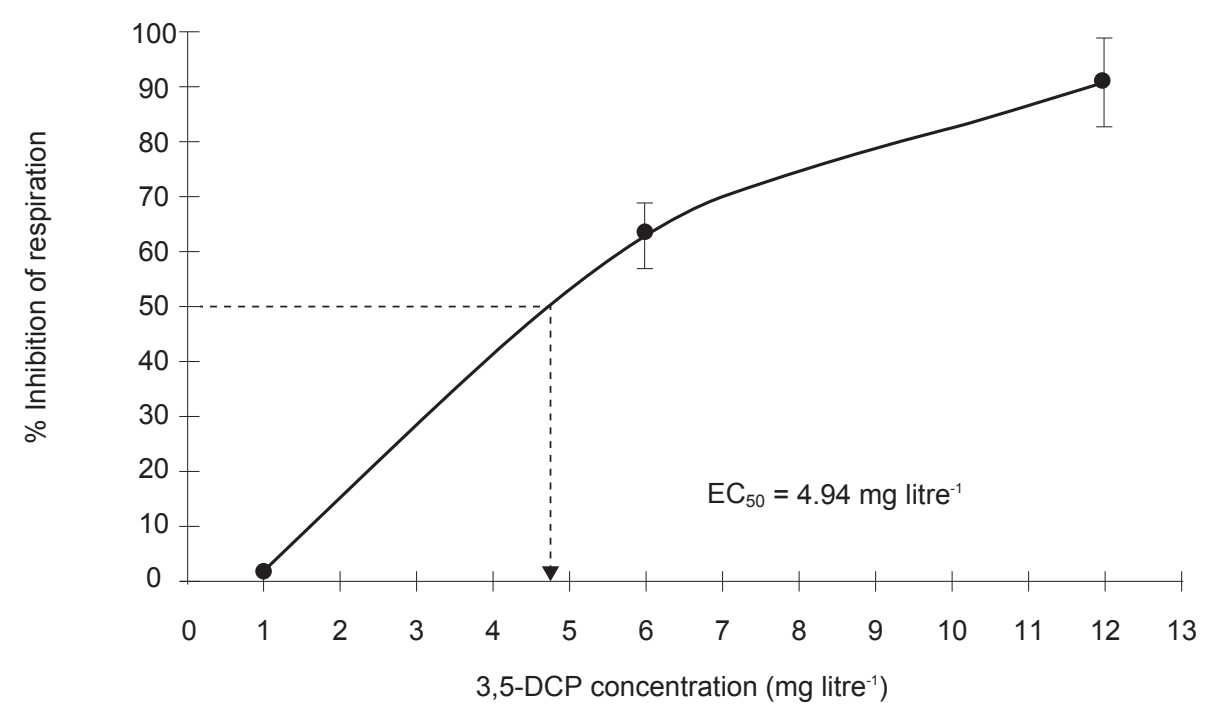

Figure 1. Microbial respiration inhibition of 3,5-dichlorophenol.

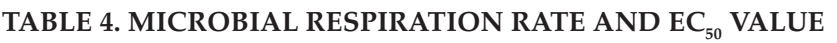

\begin{tabular}{|c|c|c|c|c|c|}
\hline & EO3 & EO5 & EO6 & EO7 & EO10 \\
\hline $\begin{array}{l}\text { Blank } \\
\mathrm{O}_{2} \text { respiration rate, } \mathrm{R}_{\mathrm{C}} \\
\left(\mathrm{mg} \mathrm{O}_{2} \text { litre }^{-1} \mathrm{hr}^{-1}\right) \pm \mathrm{SD}\end{array}$ & $\begin{array}{c}19.92 \\
\pm 2.73\end{array}$ & $\begin{array}{l}14.22 \\
\pm 1.12\end{array}$ & $\begin{array}{l}16.20 \\
\pm 1.56\end{array}$ & $\begin{array}{r}16.20 \\
\pm 1.56\end{array}$ & $\begin{array}{l}23.04 \\
\pm 2.19\end{array}$ \\
\hline $\begin{array}{l}\text { Test substance } \\
\mathrm{O}_{2} \text { respiration rate, } \mathrm{R}_{\mathrm{TI}} \\
\left(\mathrm{mg} \mathrm{O}_{2} \text { litre }^{-1} \mathrm{hr}^{-1}\right) \pm \mathrm{SD}\end{array}$ & $\begin{array}{c}6.42 \\
\pm 0.23\end{array}$ & $\begin{array}{c}8.28 \\
\pm 1.20\end{array}$ & $\begin{array}{c}9.48 \\
\pm 1.89\end{array}$ & $\begin{array}{l}14.28 \\
\pm 1.94\end{array}$ & $\begin{array}{r}15.18 \\
\pm 2.79\end{array}$ \\
\hline$\%$ Inhibition of respiration, $\mathrm{I}_{\mathrm{TI}}$ & 68 & 42 & 42 & 40 & 34 \\
\hline $3 \mathrm{~h}-\mathrm{EC}_{50}\left(\mathrm{mg}\right.$ litre $\left.^{-1}\right)$ & 423 & $>1000$ & $>1000$ & $>1000$ & $>1000$ \\
\hline GESAMP rating scheme & Practically non-toxic & Non-toxic & Non-toxic & Non-toxic & Non-toxic \\
\hline
\end{tabular}

Note: SD - standard deviation.

GESAMP - Group of Experts on the Scientific Aspects of Marine Environmental Protection (GESAMP).

High respiration rate or rapid decrease of oxygen was observed in blanks. This indicates high bacterial activity in the sludge. The inhibition of microbial respiration or decreased oxygen consumption was observed after introduction of FAEO.

At $1000 \mathrm{mg}$ litre ${ }^{-1}$, only FAEO (EO3) inhibited more than $50 \%$, while other samples less than $50 \%$ (Figure 2). FAEO (EO3) had the highest percentage of microbial respiration inhibition, while FAEO (EO10) showed the lowest respiration inhibition percentage. The toxicity level of FAEO decreased as the number of EO increased. The $3 \mathrm{hr}-\mathrm{EC}_{50}$ value for FAEO (EO3) was $423 \mathrm{mg}$ litre $^{-1}$ (Figure 3). The $3 \mathrm{hr}-$ $\mathrm{EC}_{50}$ for other samples tested were $>1000 \mathrm{mg} \mathrm{litre}^{-1}$. According to Group of Experts on the Scientific Aspects of Marine Environmental Protection (GESAMP) rating scheme, FAEO (EO3) sample falls under the category of 'practically non-toxic' while, others are considered as 'non-toxic' (Table 4).

Surfactants may interact with microorganisms, causing inhibition of growth or damage to cellular components. Nonionic surfactants are generally less toxic than cationic and anionic surfactants. Inhibitory activity depends on specific environmental conditions: the types and concentrations of surfactants present, the types and acclimation history of bacterial species, and the presence of foods and other materials. In general, toxicity to bacteria increases with increasing hydrophobic chain length and decreases with increasing ethoxylate chain length (Swisher, 1987).

\section{Biodegradability of FAEO Based on OECD 301C MITI Method}

Viability of inoculum. The viability of the collected and pre-conditioned activated sludge from 10 sites used as inoculum in test method OECD 301C MITI was measured weekly via plate counts for three months. According to the method, the collected inoculum can be used up to four months. The highest number of bacteria was observed after six weeks of aeration (Figure 4), which was 491 fold higher compared to Week 2. After six weeks, the number of bacteria decreased; therefore, the sludge cannot be used as inoculum. According to Nyholm 


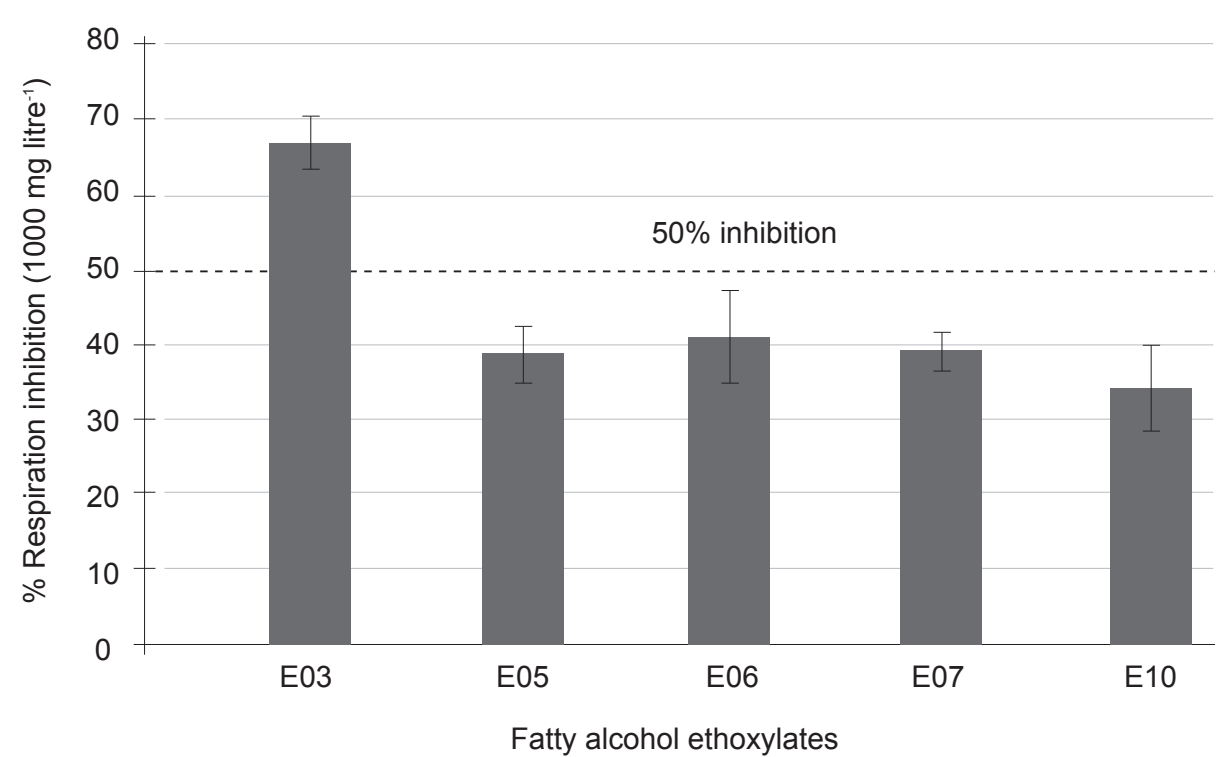

Figure 2. Percentage of microbial respiration inhibition for FAEO with different EO numbers.

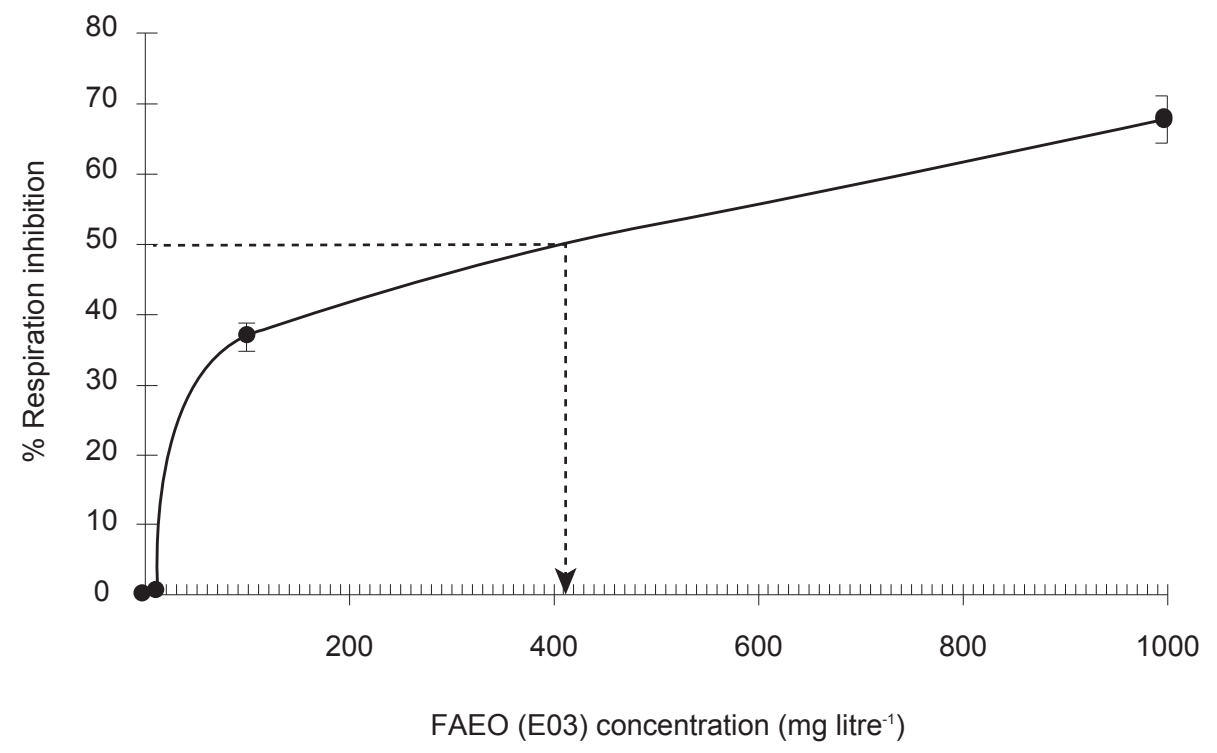

Figure 3. Respiration inhibition (\%) of microbial in sample FAEO (EO3).

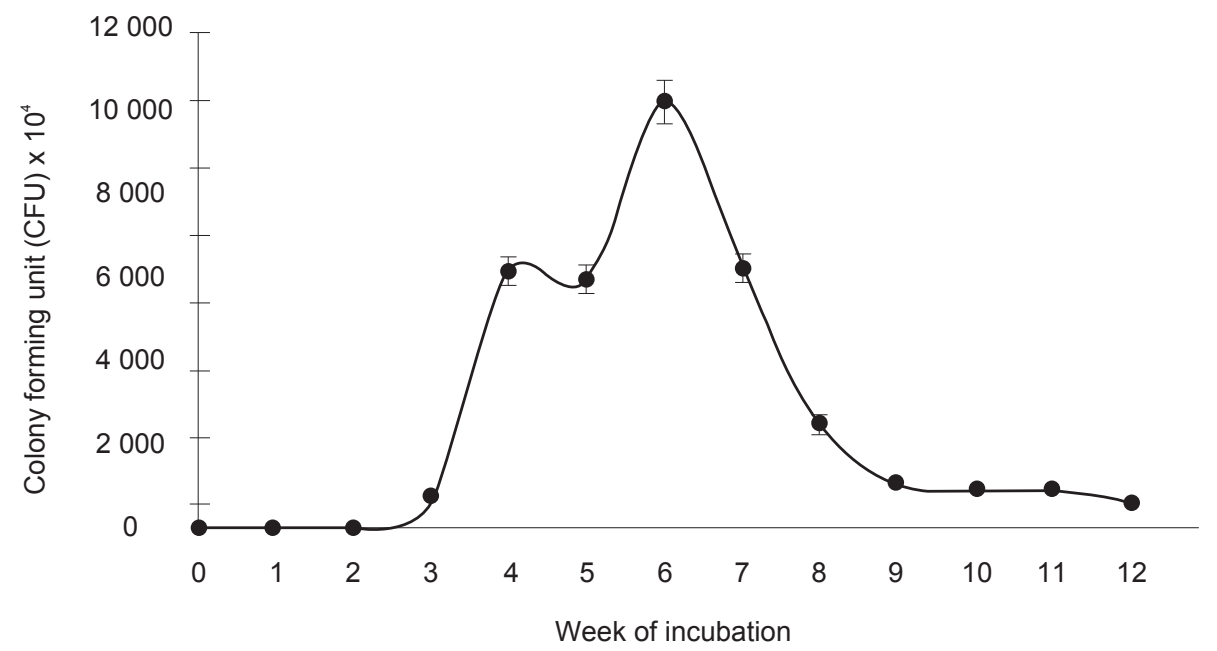

Figure 4. Colony counts of inoculum. 

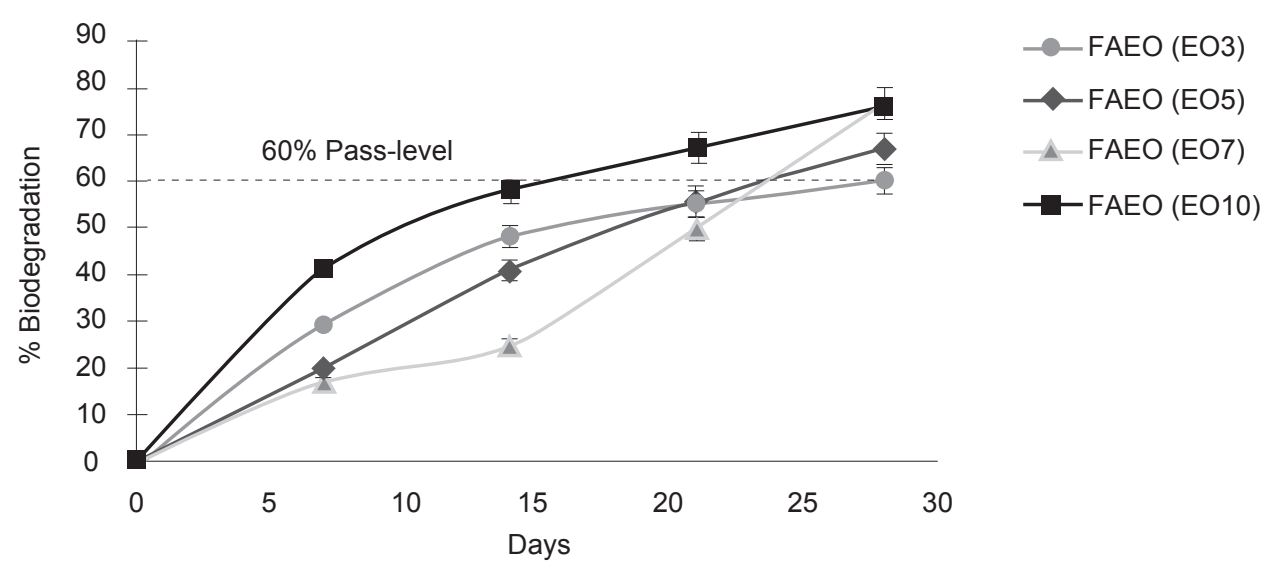

Figure 5. Biodegradation curves of FAEO samples.

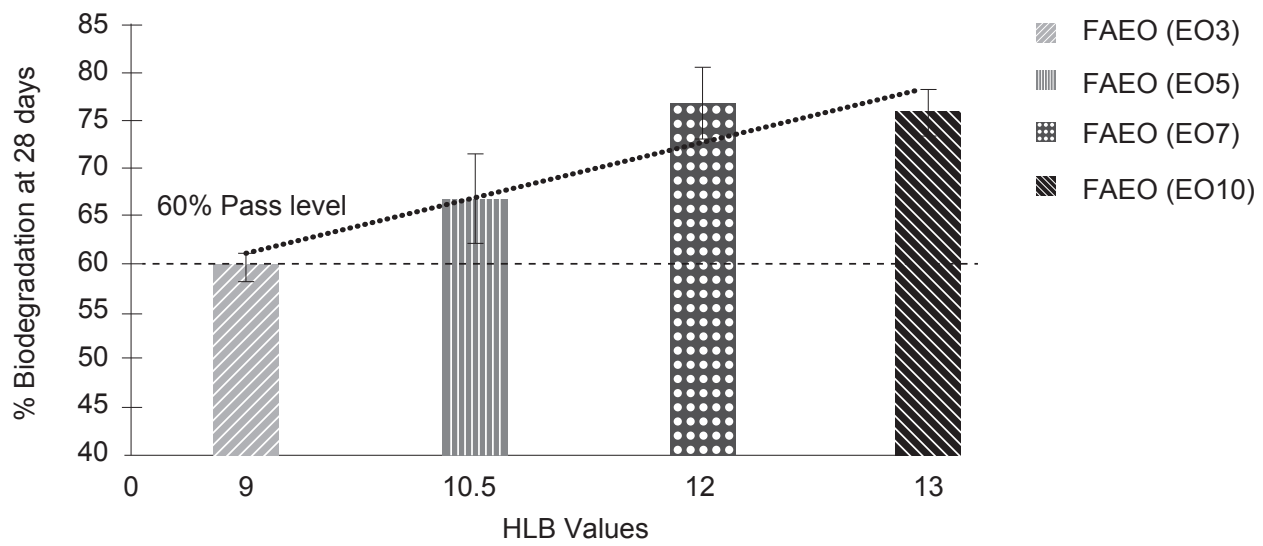

Figure 6. The correlation between FAEO biodegradation and HLB values.

(1991), due to long pre-culture process in MITI tests, the bacterial diversity in sludge inoculum will decrease and the biodegradation potential may be weakened due to change of bacterial structure.

\section{Biodegradation of Fatty Alcohol Ethoxylates}

The biodegradability of commercial FAEO with different EO numbers is presented in Figure 5. In the OECD 301 test method, any substance that reaches $60 \% \mathrm{BOD} / \mathrm{ThOD}$ is considered as 'readily biodegradable' in the environment (OECD, 1992). Figure 5 shows that all FAEO samples can be considered as 'readily biodegradable', where the percentages of biodegradation were more than $60 \%$ within the test period. The biodegradation rate of FAEO increased with increasing $\mathrm{EO}$ numbers. FAEO (EO10) underwent the highest biodegradability rate, i.e. $76 \%$ at Day 28 , while the lowest was FAEO (EO3), i.e. $60 \%$ in 28 days.

According to Dorn et al. (1993), the biodegradability of alcohol ethoxylate is not affected by the alkyl carbon chain length, but is affected by the molecular structure of hydrophobic chain. Increased solubility though increased EO chain length promotes the biodegradability of alcohol ethoxylates in the environment.

According to Jurado et al. (2013), the biodegradation of ether carboxylic surfactants with shorter alkyl chains was higher than surfactants with longer alkyl chains. For surfactants with similar chain length, biodegradability was higher for those with higher degree of ethoxylation as observed in this study. However, Scharer et al. (1979) and Holt et al. (1992) observed that the biodegradation rate was slow for branched alcohol ethoxylate $(\mathrm{EO}>20)$. Nina and Thomas (2004) showed that alcohol ethoxylate was readily biodegradable in activated sludge but the biodegradation rate varied depending to its carbon chain length and number of EO.

The biodegradability of nonionic surfactants is simultaneously influenced by several parameters such as hydrophobic structure, linearity of the carbon backbone, length of the alkyl chain, the type of bond to the EO, and its length. According 
to Jurado et al. (2007), there seems to be a positive correlation between biodegradation and the HLB values. HLB describes the relationship between water-soluble and oil-soluble parts of nonionic surfactant. Higher HLB value indicates higher solubility of the surfactant in water.

The results in this study showed that by increasing the EO number or the polar head of FAEO, the HLB value tended to increase while the hydrophobicity decreased. The reduction in hydrophobicity level of FAEO increases its solubility in water, thus promotes rapid biodegradation in aquatic environment (Figure 6).

\section{CONCLUSION}

The results of OECD 209, activated sludge, respiration inhibition test, showed FAEO (EO3) sample with a maximum concentration of $1000 \mathrm{mg} \mathrm{litre}^{-1}$ inhibited more than $50 \%$ respiration of activated sludge, while other samples did not cause more than 50\% respiration inhibition to activated sludge after $3 \mathrm{hr}$ of exposure. All FAEO samples can be considered as practically non-toxic to non-toxic towards microbial respiration. The toxicity effect of FAEO decreases with increasing ethoxylate number. Evaluation of biodegradability of poorly water soluble substances can be done using ready biodegradability test, i.e. OECD 301C MITI. The FAEO samples were readily biodegraded using this test method where their biodegradability surpassed the $60 \%$ pass level and can be considered as readily biodegradable in the environment as stated in the standard method.

\section{ACKNOWLEDGEMENT}

The authors would like to thank the DirectorGeneral of MPOB for permission to publish this article. Thanks are also extended to members of the Environmental and Product Assessment (EPA) Unit of Advanced Oleochemical Technology Division (AOTD) for their technical assistance and support.

\section{REFERENCES}

Allied Market Research (2018). Global surfactants market expected to reach \$64 408 million, by 2025. https: / / www.alliedmarketresearch.com/pressrelease/surfactants-market.html/., accessed on 3 August 2019.

Baumann, H and Biermann, M (1994). Oleochemical surfactants today. Elaeis Vol. 6: 49-64.

Diana, C L W; Philip, B D and Eric, Y C (1997). Acute toxicity and structure-activity relationships of nine alcohol ethoxylate surfactants to fathead minnow and Daphnia magna. Environ Toxicol Chem., 16: 1970-1976. DOI: https://doi.org/10.1002/ etc. 5620160929 .

Dorn, P B; Salanitro, J P; Evans, S H and Kravetz, L (1993). Assessing the aquatic hazard of some branched and linear nonionic surfactants by biodegradation and toxicity. Environ. Toxicol. Chem., 12: 1751-1762. DOI: https://doi.org/10.1002/ etc.5620121002.

Eadsforth, C V; Sherren, A J; Selby, M A; Toy, R; Eckhoff, W S and Mcavoy, D C (2006). Monitoring of environmental fingerprints of alcohol ethoxylates in Europe and Canada. Ecotoxicol. Environ. Saf., 64: 14-29. DOI:10.1016/j.ecoenv.2005.06.009.

ECETOC (1986). Biodegradation test for poorlysoluble compounds. Technical Reports. European Chemical Industry. Brussel, Belgium. p. 23.

Environment Canada (2003). Alcohol Ethoxylates, Federal Environmental Quality Guidelines, Canadian Environmental Protection Act, 1999, Canada. p. 20.

Goyer, M M; Perwak, J H; Sivak, A and Thayer, P S A (1981). Human Safety and Environmental Aspects of Major Surfactants (supplement). Report to the Soap and Detergent Association. p. 291.

Guhl, W and Gode, P (1989). Correlations between lethal and chronic/biocenotic effect concentrations of surfactants. Tenside Surfact. Det., 26: 282-287.

Hall, W S; Patoczka, J B; Mirenda, R J; Porter, B A and Miller, E (1989). Acute toxicity of industrial surfactants to Mysidopsis bahia. Arch. Environ. Contam. Toxicol., 18: 765-772. DOI: 10.1007/ bf01225014.

HERA (2009). Human and environmental risk assessment on ingredients of European household cleaning products. Alcohol Ethoxylates. https:/ / www.heraproject.com/files/34-F-09 HERA AE Report Version 2-3 Sept 09.pdf, accessed on 13 July 2018.

Holt, M S; Mitchell, G C and Watkinson, R J (1992). The environmental chemistry, fate and effects of nonionic surfactants. The Handbook of Environmental Chemistry (Hutzinger, $\mathrm{O}$ ed.). Vol. 3 Part F: Anthropogenic compounds - Detergents. SpringerVerlag, Berlin. p. 398.

Jasna, H and Tomislav, I (2007). Toxicity of anionic and cationic surfactant to Acinetobacter junii in pure culture. Central European J. Biology, 3: 405-414. DOI: 10.2478/s11535-007-0029-7. 
Jurado, E; Fernández-Serrano, M; Ríos, F and Lechuga, M (2013). Aerobic biodegradation of surfactants. Biodegradation - Life of Science. Intech, 63-81. DOI: http:/ / dx.doi.org/10.5772/56120.

Jurado, E; Fernandez-Serrano, M; Nũez-Olea, J and Lechuga, M (2007). Primary biodegradation of commercial fatty-alcohol ethoxylate surfactants: Characteristic parameters. J. Surfact Deterg, 10: 145153. DOI: $10.1007 /$ s11743-007-1027-5.

Kravetz, L; Chung, H; Guin, KF; Shebs, WT and Smith, L S (1984). Primary and ultimate biodegradation of an alcohol ethoxylate and a nonylphenol ethoxylate under average winter conditions in the United States. Tenside Detergent, 21: 1-6.

Kushairi, A; Ong-Abdullah, M; Balu N; Hishamuddin, E; Izuddin, Z B; Razmah, G; Subramaniam, V; Sundram, S and Parveez, G K A (2019). Oil palm economic performance in Malaysia and R\&D progress in 2018. J. Oil Palm Res. Vol. 31(2): 165-194. DOI: https://doi.org/10.21894/ jopr.2019.0026.

Linda, P (2012). Screening Methods for Aquatic Toxicity of Surfactants. M.Sc thesis. Chalmers University of Technology, Sweden. p. 1-80.

Maki, A W and Bishop, W E (1979). Acute toxicity studies of surfactants to Daphnia magna and Daphnia pulex. Arch. Environ. Contam. Toxicol., 8: 599-612.

Markus, T M (2000). Anaerobic Biodegradation and Toxicity of Alcohol Ethoxylates. Ph.D thesis. Swiss Federal Institute of Technology Zürich, Switzerland. p. 1-160.

Matthijs, E; Holt, M S; Kiewiet, A and Rijs, G B J (1999). Environmental monitoring for linear alkylbenzene sulfonate, alcohol ethoxylate, alcohol ethoxy sulfate, alcohol sulfate, and soap. Environ. Toxicol. Chem., 18: 2634-2644.

Morrall, S W; Eckhoff, W S; Evans, A; Cano, M L; Dunphy, J C and Mcavoy, D C (2006). Removal of alcohol ethoxylates and environmental exposure determination in the United States sewage treatment. Ecotoxicol. Environ. Saf., 64: 3-13. DOI:10.1016/j. ecoenv.2005.07.014.
Nina, I and Thomas, F (2004). Effect of ethoxylate number and alkyl chain length on the pathway and kinetics of linear alcohol ethoxylate biodegradation in activated sludge. Environmental Toxicology and Chemistry, 23: 2790-2798.

Nyholm, N (1991). The European system of standardised legal tests for assessing the biodegradability of chemicals. Environ.. Toxicol. Chem., 10: 1237-1246. DOI: https://doi. org / 10.1002/ etc.5620101002.

OECD 209 (2010). Guideline for Testing Chemicals: Activated Sludge, Respiration Inhibition Test (carbon and ammonium oxidation). Organisation for Economic Co-operation and Development, Paris. p. 1-18.

OECD (1992). Guideline for Testing Chemicals: Ready Biodegradability. Organisation for Economic Cooperation and Development, Paris. p. 18-23.

Scharer, D H; Kravetz, L and Carr, J B (1979). Biodegradation of nonionic surfactants. Tappi., 62: 75-78.

Swisher, R D (1987). Surfactant biodegradation. Surfactant Science Series 18. Second edition. Marcel Dekker Inc., New York and Basel. p. 1120.

Talmage, S (1994). Environmental and Human Safety of Major Surfactants - Alcohol Ethoxylates and Alkylphenol Ethoxylates. A Report to the Soap and Detergent Association (SDA), CRC-Press, Florida, US. p. 374 .

Van De Plassche, E J; De Bruijn, J H M; Stephenson, R R; Marshall, S J; Feijtel, T C J and Belanger, S E (1999). Predicted no-effect concentrations and risk characterisation of four surfactants: Linear alkyl benzene sulfonate, alcohol ethoxylates, alcohol ethoxylated sulfates and soap. Environ. Toxicol. Chem., 18: 2653-2663. DOI: https://doi. org/10.1002/ etc.5620181135.

Wildish, A (1976). Lethal response by Atlantic salmon parr to some polyethoxylated cationic and nonionic surfactants. Water Res., 8: 433-437. DOI: 10.1016/ 0043-1354(74)90074-8. 